\title{
ANALISIS DAYA DUKUNG DAN DAYA TAMPUNG LAHAN PENGEMBANGAN PERUMAHAN DAN PEMUKIMAN PROVINSI BANTEN
}

\author{
Ernamaiyanti ${ }^{1)}$, Mega Yunanda ${ }^{2)}$ \\ ${ }^{1)}$ Peneliti, Ahli Lingkungan dan Konsultan Publik Jakarta, E-mail : \\ ${ }^{2)}$ Dosen Teknik Sipil Hydro Universitas Palembang, E-mail : megayunanda@unpal.ac.id
}

\begin{abstract}
Daya dukung dukung dan daya tampung lahan perlu diperhatikan untuk pengembangan perumahan dan pemukiman penduduk sehingga dapat menjaga keseimbangan antara kebutuhan dan keterbatasan dari lingkungan. Tujuan dari penelitian ini adalah untuk menganalisis daya dukung dan daya tampung lahan pengembangan perumahan dan pemukiman penduduk Provinsi Banten. Penelitian yang digunakan melalui pendekatan studi kasus (case study approach). Rancangan penelitian yaitu penelitian eksplanatori. Penelitian ini dilakukan pada bulan Agustus sampai November 2017 di Provinsi Banten. Jenis data pada penelitian ini berupa data primer dan data sekunder. Metode proyeksi penduduk yang digunakan yaitu metode Ekstrapolasi, Teknik pengukuran dan penentuan daya dukung berdasarkan daya dukung pemukiman Permen LH No.17 Tahun 2009 Tentang Pedoman Daya Dukung Lingkungan Hidup Dalam Penataaan Ruang Wilayah. Analisa kemampuan lahan dan analisis Daya Tampung Perumahan dan Kawasan Permukiman menggunakan aplikasi ArcGis. Provinsi Banten mampu menampung penduduk untuk bermukim (membangun rumah) dalam wilayah tersebut pada Tahun 2030. Kemampuan lahan di Provinsi Banten dengan kemampuan pengembangan agak tinggi adalah 550.057,28 Ha, kemampuan pengembangan sedang adalah 373.125,22 Ha dan kemampuan pengembangan rendah adalah 2.463,87 Ha. Hasil analisis menggunakan aplikasi ArcGis, daya tampung lahan di Provinsi Banten lebih besar dari pada kebutuhan lahan untuk perumahan hingga tahun rencana. Beberapa kota di Provinsi Banten hingga tahun 2030 harus mulai mengembangkan permukiman di wilayah sekitarnya dan atau mengembangkan permukiman dengan konsep vertikal seperti Kota Tangerang Selatan dan Kota Tangerang.
\end{abstract}

\section{Kata Kunci:}

Daya dukung dan daya tampung lahan, pengembangan, perumahan dan pemukiman, kemampuan lahan.

\section{PENDAHULUAN}

Provinsi Banten secara astronomis terletak antara 507'50" - 701'1" LS dan 10501'11" -10607'12" BT. Luas wilayah Banten mencapai $9.662,92 \mathrm{~km}^{2}$ atau sekitar 0,51 persen dari luas seluruh daratan Indonesia. Provinsi ini mempunyai pulau kecil sejumlah 61 pulau dengan Sungai Cisadane merupakan sungai terpanjang sekitar $414,3 \mathrm{~km}$, danau terluas yaitu Danau Cipondoh sekitar 126 ha dan Gunung Halimun merupakan gunung tertinggi di Banten yaitu mempunyai ketinggian $1.925 \mathrm{~m} \mathrm{dpl}$ (RP3KP Provinsi Banten. 2017).

Penduduk Banten berdasarkan proyeksi penduduk tahun 2015 sebanyak 11.955.243 jiwa.
Dibandingkan dengan proyeksi jumlah penduduk tahun 2014, penduduk Banten mengalami pertumbuhan sebesar 2,14 persen. Laju pertumbuhan penduduk Provinsi ini tahun 20142015 sekitar 2,14\%. Dimana laju pertumbuhan tertinggi berada pada Kota Tangerang Selatan sekitar 3,36\% dan laju pertumbuhan terkecil berada pada Kabupaten Pandeglang 0,55 \% (Provinsi Banten Dalam Angka. 2016).

Perumahan dan permukiman merupakan salah satu kebutuhan dasar manusia dalam rangka peningkatan dan pemerataan kesejahteraan rakyat. Terwujudnya kesejahteraan rakyat ditandai dengan meningkatnya kualitas kehidupan yang layak dan bermartabat melalui 
pemenuhan kebutuhan papan sebagai salah satu kebutuhan dasar manusia.

Perumahan dan permukiman merupakan kegiatan yang bersifat multi sektor, yang hasilnya langsung menyentuh salah satu kebutuhan dasar masyarakat. Persoalan yang dihadapi pun tidak lepas dari aspek yang berkembang dalam dinamika kehidupan masyarakat serta kebijakan pemerintah dalam mengelola persoalan yang ada. Agar penyelenggaraan pembangunan perumahan dan permukiman berjalan optimal, tertib dan terorganisasi dengan baik, maka prosesnya dilaksanakan secara bertahap melalui tahap persiapan, perencanaan, pelaksanaan, pengelolaan, pemeliharaan dan pengembangan. Pengembangan perumahan dan pemukiman penduduk berhubungan dengan daya dukung lahan yang mengandung dua komponen utama, yaitu ketersediaan potensi sumberdaya alam dan daya tampung lingkungan (Silalahi. 2011). Penggunaan lahan di Provinsi Banten berdasarkan RTRW terdiri dari: budidaya lahan basah, budidaya lahan kering, kawasan perkebunan, permukiman dan sumber air dengan luas total yaitu 933.878,94 Ha (Peraturan Daerah Provinsi Banten Nomor 2 Tahun 2011)

Tujuan dari penelitian ini adalah untuk menganalisis daya dukung dan daya tampung lahan pengembangan perumahan dan pemukiman penduduk Provinsi Banten.

\section{METODOLOGI}

Penelitian yang digunakan melalui pendekatan studi kasus (case study approach) yaitu keseluruhan kabupaten/kota yang ada di wilayah Provinsi Banten. Rancangan penelitian yaitu penelitian eksplanatori. Dimana pada penelitian

ini

bertujuan untuk menganalisis hubunganhubungan antara satu variabel dengan variabel lainnya atau bagaimana suatu variabel mempengaruhi variabel lainnya (Sugiyono. 2014).

Penelitian ini dilakukan pada bulan Agustus sampai November 2017 di Provinsi Banten. Jenis data pada penelitian ini berupa data primer dan data sekunder.

Metode pengumpulan data dan informasi melalui: 1) studi literature dan survei sekunder, 2) pengamatan langsung melalui survey lapangan; 3) wawancara mendalam (in-depth interview); 4. FGD
Metode proyeksi penduduk yang digunakan yaitu metode Ekstrapolasi, yaitu: $P t=P o+b(\varnothing)$

Dimana:

$\mathrm{Pt}=$ penduduk yang akan di proyeksi

Po $=$ jumlah penduduk pada tahun awal

$\mathrm{b}=$ rata-rata pertambahan penduduk

$\emptyset=$ kurun waktu proyeksi.

Teknik pengukuran dan penentuan daya dukung berdasarkan daya dukung pemukiman dirumuskan:

$$
D D P m=\frac{L P m / J P}{\alpha}
$$

(Permen LH No.17 Tahun 2009 Tentang

Pedoman Daya Dukung Lingkungan Hidup

Dalam Penataaan Ruang Wilayah)

Keterangan:

DDPm $=$ Daya dukung pemukiman

JP = Jumlah penduduk

$\alpha \quad=$ Koefisien luas kebutuhan $\left(\mathrm{m}^{2} /\right.$ kapita $)$

$\mathrm{LPm}=$ Luas lahan yang layak untuk pemukiman $\left(\mathrm{m}^{2}\right)$

$\mathbf{L P m}=\mathbf{L W}-(\mathbf{L K L}+\mathbf{L K R B})$

LW = Luas wilayah

LKL = Luas kawasan lindung

LKRB =Luas kawasan rawan bencana

DDPm $>1$ : mampu menampung penduduk untuk bermukim

$\mathrm{DDPm}=1$ : terjadi keseimbangan antara penduduk yang bermukim (membangun rumah) dengan luas wilayah yang ada

DDPm $<1$ : tidak mampu menampung penduduk untuk bermukim (membangun rumah) dalam wilayah tersebut.

Analisa kemampuan lahan dan analisis Daya Tampung Perumahan dan Kawasan Permukiman menggunakan aplikasi ArcGis.

\section{HASIL DAN PEMBAHASAN}

\section{Analisis Daya Dukung}

Daya dukung merupakan indikasi kemampuan mendukung penggunaan tertentu, sedangkan daya tampung adalah indikasi toleransi mendukung perubahan penggunaan 
tertentu (atau pengelolaan tertentu) pada unit spasial tertentu.

Analisis daya dukung (carrying capacity ratio) merupakan suatu alat perencanaan pembangunan yang memberikan gambaran hubungan antara penduduk, penggunaan lahan dan lingkungan. Dari semua hal tersebut, analisis daya dukung dapat memberikan informasi yang diperlukan dalam menilai tingkat kemampuan lahan dalam mendukung segala aktivitas manusia yang ada di wilayah yang bersangkutan.

Penentuan daya dukung dan daya tampung lingkungan hidup merupakan instrumen yang menjelaskan proses/cara kajian ilmiah untuk menentukan/mengetahui kemampuan suatu wilayah dalam mendukung kebutuhan hidup manusia dan makhluk hidup lainnya. Oleh karena itu dalam penentuan daya dukung dan daya tampung lingkungan hidup dilakukan melalui pendekatan indikatif berdasarkan unit analisis, parameter, indikator dan tolok ukur pada masingmasing unit analisis tersebut. Mengingat daya dukung dan daya tampung bersifat dinamis dan kompleks dan sangat tergantung kepada karakteristik geografi suatu wilayah, jumlah penduduk dan kondisi eksisting sumber daya alam di wilayahnya masing-masing.

Daya dukung lahan merupakan salah satu permasalahan dalam pemenuhan kebutuhan rumah khususnya bagi MBR. Hal ini berkaitan dengan keterjangkauan daya beli masyarakat untuk memenuhi kebutuhan papan dan keterbatasan lahan apalagi di perkotaan (Syarif. 2011).

Dari hasil perhitungan didapat DDPm Provinsi Banten di dapat 13.58 artinya DDPm Provinsi Banten $>1$, maknanya Provinsi Banten mampu menampung penduduk untuk bermukim (membangun rumah) dalam wilayah tersebut pada Tahun 2030. Daya dukung pemukiman Provinsi Banten Tahun 2030 per Kabupaten/ Kota di sajikan Tabel di bawah ini.
Tabel 1. Daya Dukung Pemukiman Provinsi Banten Tahun 2030

\begin{tabular}{|c|c|c|c|}
\hline NO & $\begin{array}{c}\text { KABUPATEN/ } \\
\text { KOTA }\end{array}$ & DDPM & KETERANGAN \\
\hline 1. & $\begin{array}{l}\text { Kabupaten } \\
\text { Pandeglang }\end{array}$ & 49,465 & $\begin{array}{l}\text { Mampu } \\
\text { menampung } \\
\text { penduduk untuk } \\
\text { bermukim }\end{array}$ \\
\hline 2. & $\begin{array}{l}\text { Kabupaten } \\
\text { Lebak }\end{array}$ & 24,598 & $\begin{array}{l}\text { Mampu } \\
\text { menampung } \\
\text { penduduk untuk } \\
\text { bermukim }\end{array}$ \\
\hline 3. & $\begin{array}{l}\text { Kabupaten } \\
\text { Tangerang }\end{array}$ & 20,439 & $\begin{array}{l}\text { Mampu } \\
\text { menampung } \\
\text { penduduk untuk } \\
\text { bermukim }\end{array}$ \\
\hline 4. & $\begin{array}{l}\text { Kabupaten } \\
\text { Serang }\end{array}$ & 0,711 & $\begin{array}{l}\text { Tidak mampu } \\
\text { menampung } \\
\text { penduduk untuk } \\
\text { bermukim } \\
\text { (membangun } \\
\text { rumah di wilayah } \\
\text { tersebut) }\end{array}$ \\
\hline 5. & Kota Serang & 9,067 & $\begin{array}{l}\text { Mampu } \\
\text { menampung } \\
\text { penduduk untuk } \\
\text { bermukim }\end{array}$ \\
\hline 6. & Kota Cilegon & 1,451 & $\begin{array}{l}\text { Mampu } \\
\text { menampung } \\
\text { penduduk untuk } \\
\text { bermukim }\end{array}$ \\
\hline 7. & Kota Tangerang & 0,443 & $\begin{array}{l}\text { Tidak mampu } \\
\text { menampung } \\
\text { penduduk untuk } \\
\text { bermukim } \\
\text { (membangun } \\
\text { rumah di wilayah } \\
\text { tersebut) }\end{array}$ \\
\hline 8. & $\begin{array}{l}\text { Kota Tangerang } \\
\text { Selatan }\end{array}$ & 2,484 & $\begin{array}{l}\text { Mampu } \\
\text { menampung } \\
\text { penduduk untuk } \\
\text { bermukim }\end{array}$ \\
\hline
\end{tabular}

Sumber: Hasil Analisis, 2017

DDPm $>1$

Mampu menampung penduduk untuk bermukim 
Tabel di atas menjelaskan Proyeksi pada tahun 2030 Kabupaten Tangerang dan Kota Tangerang tidak mampu menampung penduduk untuk bermukim (membangun rumah). Sedangkan untuk Kota Serang dan Kota Tangerang Selatan sudah harus memperhatikan DDDT dalam pembangunan rumah.

Perkembangan kabupaten/kota yang tidak seimbang dengan ketersediaan lahan dan harga lahan yang tinggi dan peningkatan kebutuhan rumah, menyebabkan penurunan daya dukung lahan. Menurut Prilia (2012), daya dukung lahan dalam menunjang penyediaan kebutuhan permukiman harus mempertimbangkan kestabilan pondasi, drainase, ketersediaan air tanah, kerentanan bencana.

\section{Analisa Kemampuan Lahan}

Konsep dasar dari pembangunan yang berkelanjutan yaitu konsep kebutuhan dan konsep keterbatasan. Konsep pemenuhan kebutuhan difokuskan untuk meningkatkan kualitas hidup manusia, sementara konsep keterbatasan adalah ketersediaan dan kapsitas yang dimiliki lingkungan untuk memenuhi kebutuhan tersebut. Agar pemanfaatan ruang di suatu wilayah sesuai

Tabel 2 di atas menjelaskan bahwa kemampuan lahan di Provinsi Banten dengan kemampuan pengembangan agak tinggi adalah $550.057,28 \mathrm{Ha}$, kemampuan pengembangan sedang adalah $373.125,22$ Ha dan kemampuan pengembangan rendah adalah $2.463,87 \mathrm{Ha}$. Kabupaten Serang merupakan Kabupaten pertama yang mempunyai kemampuan pengembangan agak tinggi yakni 85.235,64 Ha. Sementara itu Kota Serang, Kota Tangerang, Kota Tangerang Selaran dan Kabupaten Tangerang tidak memiliki kemampuan lahan yang rendah.

Daya dukung lahan dalam pemenuhan kebutuhan rumah bagi MBR, terkait aspek pengelolaan pasar tanah, pembangunan infrastruktur dan peengembangan ekonomi (Limbong, 2013). Hal ini dimaksudkan penyediaan rumah didukung oleh kemampuan daya dukung lahan, yang berpengaruh diantaranya terhadap kegiatan ekonomi dimana tanah tersebut berada akan menentukan perkembangan harga pasar dan harga rumah itu sendiri. dengan kapasitas lingkungan hidup dan sumber daya, alokasi pemanfaatan ruang harus mengindahkan kemampuan lahan.

Lahan menjadi salah satu unsur utama dalam menunjang kelangsungan kehidupan sejak manusia pertama kali menempati bumi. Lahan berfungsi sebagai tempat manusia beraktivitas untuk mempertahankan eksistensi. Aktivitas yang pertama kali dilakukan adalah pemanfaatan lahan untuk perumahan dan pemukiman. Tabel berikut melihatkan analisa kemampuan lahan Provinsi Banten.

\section{Tabel 2. Analisa kemampuan lahan Provinsi Banten}

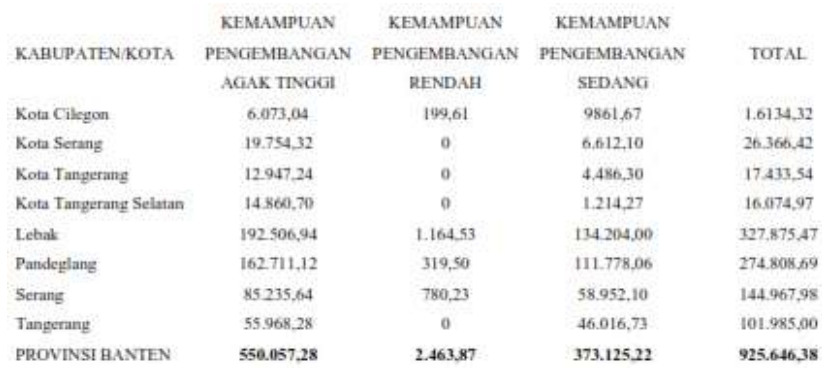

Sumber: Hasil Analisa, 2017 


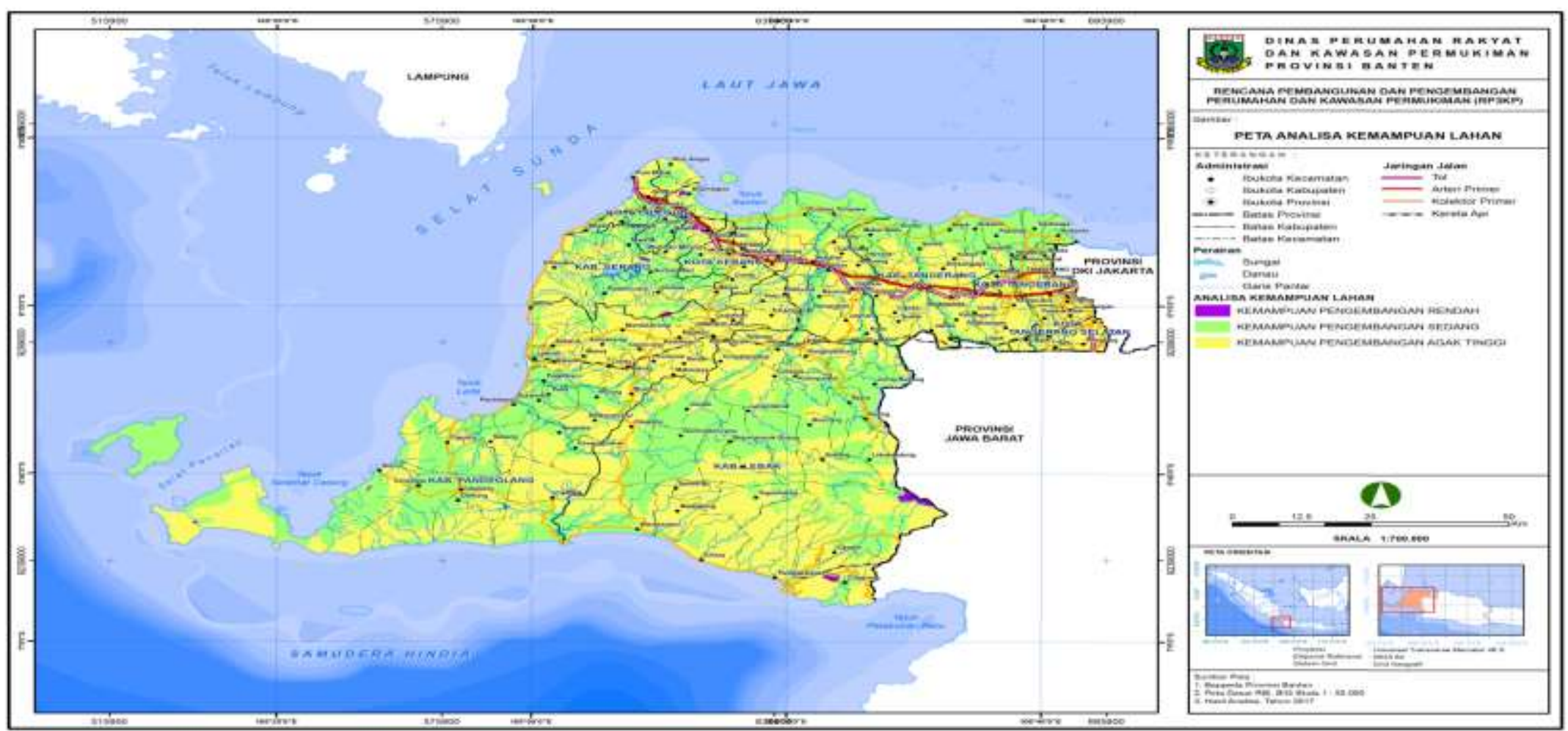

Gambar 1. Peta analisa kemampuan lahan Provinsi Banten 
Berdasarkan hasil analisis menggunakan aplikasi ArcGis, daya tampung lahan di Provinsi Banten lebih besar dari pada kebutuhan lahan untuk perumahan hingga tahun rencana. Kabupaten/kota yang memiliki daya tampung terbesar adalah Kabupaten Lebak yaitu 327.875,4708 Ha, kemudian daya tampung terbesar kedua adalah Kabupaten Pandeglang yaitu 274.808,6855 Ha. Sedangkan kabupaten atau kota yang memiliki daya tampung paling rendah adalah Kabupaten Tangerang yaitu dengan luas 144.967,9786 Ha. Untuk lebih jelasnya dapat dilihat pada tabel berikut ini:

Tabel 3. Daya Tampung Perumahan dan Kawasan Permukiman

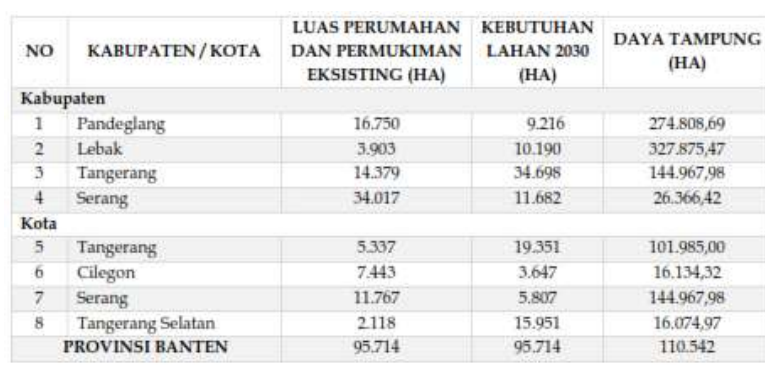

Sumber:Hasil Analisis, 2017

\section{Arah Pengembangan Perumahan dan Permukiman}

Berdasarkan peta rencana pola ruang RTRW Provinsi Banten Tahun 2030 dapat diketahui luas kawasan pengembangan untuk perumahan dan kawasan pemukiman di Provinsi Banten adalah 176.819.94 hektar. Kawasan pengembangan ini tersebar diseluruh kabupaten dan kota yang ada di Provinsi Banten. Kabupaten/kota yang memiliki areal pengembangan terluas terdapat di Kabupaten Tangerang (46.715,93 hektar), Kabupaten Serang (33.329,12 Hektar) dan Pandeglang (22.520,60 hektar). Untuk lebih jelasnya dapat dilihat pada tabel berikut ini.
Tabel 4. Luas Kawasan Perkotaan (Ha)

\begin{tabular}{|l|c|c|}
\hline $\begin{array}{c}\text { KABUPATEN/KO } \\
\text { TA }\end{array}$ & $\begin{array}{c}\text { KAWASAN } \\
\text { PERKOTAAN } \\
\text { (HA) }\end{array}$ & $\begin{array}{c}\text { JUMLAH } \\
\text { (HA) }\end{array}$ \\
\hline Kota Cilegon & $9.658,01$ & $9.658,01$ \\
\hline Kota Serang & $17.776,54$ & $17.776,54$ \\
\hline Kota Tangerang & $16.150,14$ & $16.150,14$ \\
\hline $\begin{array}{l}\text { Kota Tangerang } \\
\text { Selatan }\end{array}$ & $16.074,99$ & $16.074,99$ \\
\hline Lebak & $14.594,61$ & $14.594,61$ \\
\hline Pandeglang & $22.520,60$ & $22.520,60$ \\
\hline Serang & $33.329,12$ & $33.329,12$ \\
\hline Tangerang & $46.715,93$ & $46.715,93$ \\
\hline $\begin{array}{l}\text { PROVINSI } \\
\text { BANTEN }\end{array}$ & $\mathbf{1 7 6 . 8 1 9 , 9 4}$ & $\mathbf{1 7 6 . 8 1 9 , 9 4}$ \\
\hline
\end{tabular}

Sumber: Analisis, 2017

Hasil perhitungan dengan menggunakan data spasial berbasis sistem informasi geografis, terlihat bahwa RTRW Banten 2030 untuk alokasi lahan kawasan permukiman-perkotaan terbesar terdapat di Kabupaten Tangerang dengan komposisi sebesar 26\%, disusul oleh Kabupaten Serang, Kabupaten Pandeglang dan Kota Tangerang Selatan serta Kota Tangerang. Untuk lebih jelasnya dapat dilihat pada Gambar 2 dibawah ini.

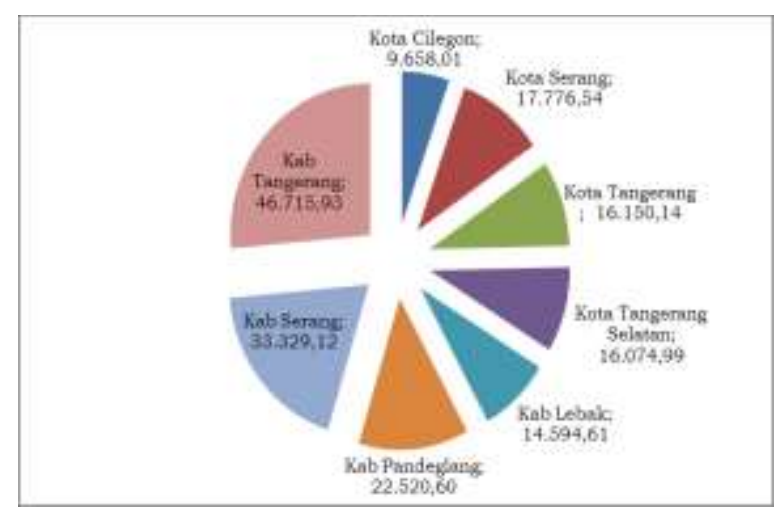

Gambar 2. Luas Lahan Permukiman Perkotaan Berdasarkan GIS pada RTRW Provinsi Banten 2030

Apabila mencermati ketersediaan lahan permukiman yang dialokasikan pada tahun 2030 sesuai RTRW Banten, maka beberapa kota harus mulai mengembangkan permukiman di wilayah sekitarnya dan atau mengembangkan permukiman dengan konsep vertikal seperti Kota Tangerang Selatan dan Kota Tangerang. Dua kota ini harus mulai mengembangkan dan menyiapkan lahan permukiman berbasis vertikal. Lihat grafik dibawah ini. 


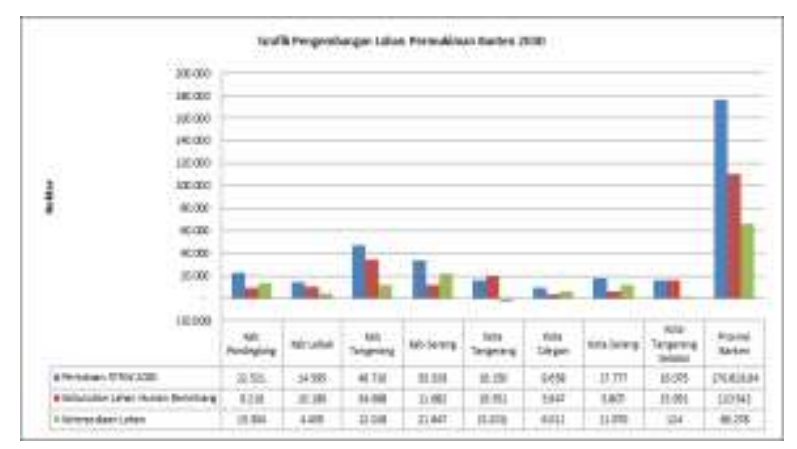

Gambar 3. Ketersediaan Lahan Permukiman Pada Tahun 2030

Namun, dari sisi ketersediaan skala wilayah provinsi dinyatakan bahwa alokasi lahan untuk kawasan perkotaan-permukiman masih cukup besar dibandingkan dengan luas lahan yang dibutuhkan untuk pengembangan hunian berimbang, ada ketersediaan sebesar 60.000 hektar tersebar di semua kabupaten, kecuali dua kota yang telah disebutkan.

Ada enam sektor yang saling berhubungan dalam pemenuhan kebutuhan rumah di perkotaan yang harus ditangani pemerintah yaitu daya dukung lahan, infrastruktur, lingkungan, fasilitas umum, fasilitas sosial dan pembangunan ekonomi (Nurmadi. 2006).

\section{KESIMPULAN}

Provinsi Banten mampu menampung penduduk untuk bermukim (membangun rumah) dalam wilayah tersebut pada Tahun 2030. Kemampuan lahan di Provinsi Banten dengan kemampuan pengembangan agak tinggi adalah $550.057,28 \mathrm{Ha}$, kemampuan pengembangan sedang adalah 373.125,22 Ha dan kemampuan pengembangan rendah adalah $2.463,87 \mathrm{Ha}$. Hasil analisis menggunakan aplikasi ArcGis, daya tampung lahan di Provinsi Banten lebih besar dari pada kebutuhan lahan untuk perumahan hingga tahun rencana. Beberapa kota di Provinsi Banten hingga tahun 2030 harus mulai mengembangkan permukiman di wilayah sekitarnya dan atau mengembangkan permukiman dengan konsep vertikal seperti Kota Tangerang Selatan dan Kota Tangerang.

\section{DAFTAR PUSTAKA}

BPS. 2016. Banten dalam Angka. Badan Pusat Statistik. Banten

Limbong, B. 2013. Bank Tanah. Pustaka Margareta. Jakarta.

Nurmadi, A. 2006. Manajemen Perkotaan: Aktor, Organisasi, Pengelolaan Daerah Perkotaan dan Metropolitan di Indonesia. Sinergi Publishing. Yogyakarta

Peraturan Menteri Negara Lingkungan Hidup Nomor 17 Tahun 2009. Pedoman Penentuan Daya Dukung Lingkungan Hidup dalam Penataan Ruang Wilayah.

Peraturan Daerah Provinsi Banten Nomor 2 Tahun

2011

Tentang Rencana Tata Ruang Wilayah Provinsi Banten Tahun 2010-2030

Prilia, A. 2012. Pengaruh Kesesuaian Lahan untuk Permukiman terhadap Daya Dukung Lahan. Jurnal Universitas Taruma Negara. 5 (5):1-10

RP3KP. 2017. RP3KP Provinsi Banten. Dinas Perumahan dan Pemukiman Provinsi Banten. Serang

Syarif, Koto Zulfi. 2011 Politik Pembangunan Perumahan Rakyat di Era Reformasi. Housing and Urban Development Institute (HUD). Jakarta 